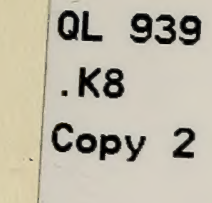




\section{METALEDGE, INC. 2000}

PH7.5 TO 9.5 PA.T. 


\section{THE DEVELOPMENT OF THE SYMPATHETIC NERVOUS SYSTEM IN MAMMALS}

BY

ALBERT KUNTZ

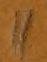

Whth Eighteen Figures

A Dissertation Submitted to the Faculty of the Graduate College of the State University of Iowa in partial fulfilment of the requirements for the Degree of Doctor of Philosophy. Vor. 20 , No. 3, J UNE, 1910. 
. 


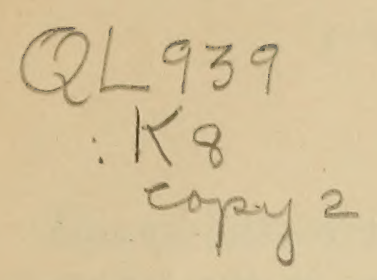

\title{
THE DEVELOPMENT OF THE SYMPATHETIC NERVOUS SYSTEM IN MAMMALS
}

\author{
ALBERT KUNTZ \\ From the Laboratories of Animal Biology of the State University of Iowa
}

WITH EIGHTEEN FIGURES

CONTENTS

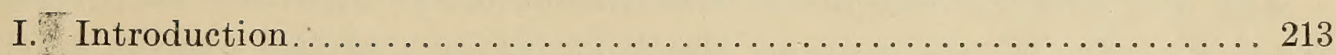

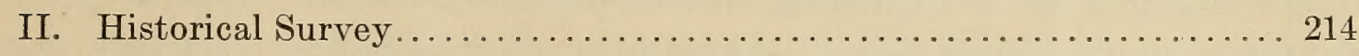

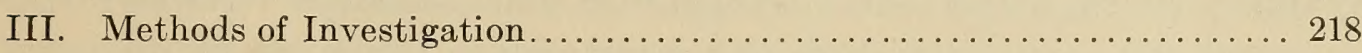

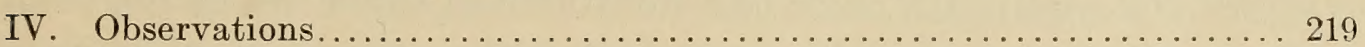

1. Sympathetic trunks.............................. 219

a. Early development.......................... 219

b. Cell migration............................ 222

c. Later development............................... 229

d. Nature of migrating cells..................... 230

2. Prevertebral plexuses............................ 233

a. Develo ment.................................... 233

b. Histogenetic relationships.................... 234

3. Vagal sympathetic plexuses ................... 235

a. Introductory ............................ 235

b. Myenteric and submucous plexuses............... 236

c. Pulmonary plexuses............................ 239

d. Cardiac plexus.................................. 239

$e$. Cell migration along the vagi................... 241

V. Discussion of Results, and Conclusions........................ 246

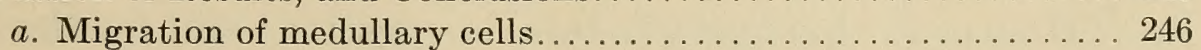

$b$. The neurilemma................................. 248

c. Sympathetic excitatory and sympathetic sensory neurones .... 249

d. A wider application of Schaper's conception............... 351

$e$. Relation of the sympathetic to the central nervous system..... 251

f. Functional relations............................ 252

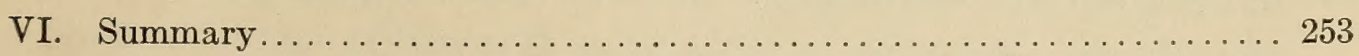

Bibliography.......................................... 256 


\section{INTRODUCTION}

The present investigation of the development of the sympathetic nervous system in mammals was carried on in the laboratories of Animal Biology of the State University of Iowa, under the direction of Prof. Gilbert L. Houser.

Although much excellent work has been done on the development of the sympathetic nervous system, our knowledge concerning the sympathetic neurones and the relation of the sympathetic to the central nervous system is still very meager. Our newer conceptions of nerve-components and of the functional divisions of the peripheral nervous system call for a re-investigation of the development of the sympathetic system in order to bring this division of the nervous system into harmony with established facts.

The present investigation was undertaken in order to further exact knowledge concerning the histogenesis of the sympathetic system, to establish the histogenetic relationships between the sympathetic neurones and the neurones in the central nervous system, and to correlate the sympathetic system with the other functional divisions of the nervous system. The most important results achieved pertain to increased knowledge concerning the histogenesis of the sympathetic system and its relation to the central nervous system, and to the fact that the cardiac plexus and the sympathetic plexuses in the walls of the visceral organs are not derived from the sympathetic trunks, as has hitherto been supposed, but have their origin in nervous elements which migrate from the vagus ganglia and the walls of the hind-brain along the fibers of the vagi. During the progress of the work, two preliminary papers were published (see Bibliography).

It is a real pleasure to express my deep sense of obligation to Prof. Houser for his many helpful suggestions and for the inspiration afforded by the constant enthusiastic interest manifested by him during the progress of this investigation. I desire also to express my indebtedness to Dr. F. A. Stromsten for many valuable suggestions in technique.

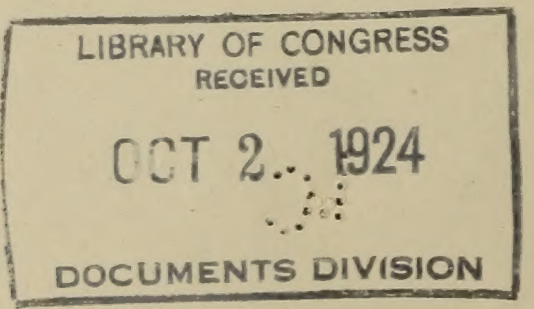




\section{HISTORICAL SURVEY}

The earliest observations on development of the sympathetic nervous system are those of Remak ('47). That pioneer among the investigators of the sympathetic system described the anlagen of the sympathetic trunks in the chick as ganglionic enlargements on the communicating rami, situated at their point of deviation from the spinal nerves. He believed that the cells composing these ganglionic enlargements are derived from preformed elements arising in the mesoderm. This view of the mesodermal origin of the sympathetic nervous system held undisputed sway for more than two decades, and has found advocates, among whom may be mentioned Paterson ('91), in more recent times.

The work of Balfour ('77) marks the beginning of our modern conception of the ectodermal origin of the sympathetic nervous system. According to his observations on the selachians, the anlagen of the sympathetic trunks arise as simple enlargements on the spinal nerve-trunks. Subsequently, these enlargements advance toward the aorta, each, however, retaining connection with its respective nerve by a fibrous branch which becomes the communicating ramus. These ganglionic enlargements are at first independent of each other, but becomeunited later bylongitudinal commissures. These observations on the selachians were substantiated by Onodi ('86), Van Wijhe ('89), and Hoffmann ('99).

Schenck and Birdsall ('78) extended the conception of Balfour, somewhat modified, to the higher vertebrates. Tracing the development of the sympathetic trunks in birds and mammals, they found that before the anlagen of the sympathetic trunks appear, the spinal ganglia are not sharply limited distally. Groups of cells become detached from the distal ends of the spinal ganglia and advance far into the spinal nerve-trunks. These cells, they believe, constitute the anlagen of the sympathetic trunks, but they have given no clear conception of the process by which these cells are transferred from the spinal ganglia to their new location in the sympathetic anlagen.

Kölliker ('97) adopted the doctrine of Balfour and attempted to extend it to the peripheral sympathetic plexuses. In the ab- 


Kohn ('05, '07) describes the anlagen of the sympathetic trunks in the rabbit as a pair of columns of cell-aggregates arising along the sides of the dorsal surface of the aorta. Similar cells are found in intermediate positions between these cell-aggregates and the spinal nerves, in the paths later occupied by the fibers of the communicating rami. According to Kohn, the sympathetic anlagen are composed of cells which arise by the division of elements which have not migrated thither, but were differentiated in situ in the spinal nerves. Embryonal neurocytes deviate from the course of the spinal nerves toward the aorta. By division they yield a syncytial cellular communicating ramus which extends toward the aorta. Cell-groups become separated from its distal end and give rise to the cell-aggregates of the sympathetic anlagen.

According to Neumayer's observations on embryos of Lacerta (spec?) and the chick ('06), the anlagen of the sympathetic trunks arise as short cellular outgrowths on the spinal nerves which early develop ganglionic enlargements at their distal ends, which become united later by longitudinal cellular commissures. Neumayer, like Kohn, traces the origin of the sympathetic system directly to the spinal nerves. He is of the opinion that in all vertebrates the sympathetic anlagen arise from cells which are to be regarded as the offspring of the dorsal and the ventral nerve-roots and are differentiated in situ, like the cells of the spinal ganglia and the fibers of the nerve-roots.

The work of Froriep ('07) on embryos of Torpedo and of the rabbit, marks a decided advance in our knowledge of the histogenesis of the sympathetic nervous system. He succeeded in tracing medullary cells peripherally along the ventral roots of the spinal nerves. These cells he formerly interpreted as elements which give rise to the neurilemma. After Harrison ('04) showed experimentally that in amphibians the cells giving rise to the neurilemma of both the sensory and the motor fibers have their origin in the neural crest, Froriep concluded that the cells migrating peripherally in the ventral nerve-roots, either alone or with cells which wander out from the spinal ganglia, give rise to the sympathetic nervous system. In his summary he expresses the opin- 
ion that all the sympathetic neurones in the sympathetic trunks as well as in the prevertebral and the peripheral sympathetic plexuses have their origin in the ventral half of the neural tube.

Held ('09) and Marcus ('09) have recently taken exception to Froriep's conclusions. Held has attempted to show, for the entire vertebrate series, that the cells present in the motor nerve-roots play no part in the development of the sympathetic system. He still regards the sympathetic systemas an offshoot from the spinal ganglia. Marcus has attempted to show that the cell-groups which Froriep observed in the ventral roots of the spinal nerves do not wander out from the neural tube, but migrate thither from the neural crest. In early stages of embryos of Torpedo, he has observed cell-chains connecting the neural crest with the cellaggregates in the ventral nerve-roots. He concludes, therefore, that the neural crest represents the sole source of all the cells giving rise to sympathetic neurones.

This brief review of the literature has shown that the advocates of the theory of the ectodermal origin of the sympathetic nervous system agree in tracing the origin of the cells giving rise to the sympathetic anlagen to the cerebro-spinal system. There is a wide difference of opinion, however, concerning the immediate source and the histogenesis of these cells.

Two views have been prevalent among the older investigators. Onodi advanced the idea that the cells at the distal ends of the spinal ganglia are forced to advance farther peripherally by the pressure exerted by the newly formed elements back of them. In this manner cell-groups become constricted off from the spinal ganglia and give rise to the anlagen of the sympathetic trunks. His, His, Jr., and some of the later writers have traced the origin of the cells giving rise to the sympathetic anlagen to the spinal ganglia, but have accounted for the transfer of these elements from the spinal ganglia to their new location by active migration, either directly through the mesenchyme or along the paths of the spinal nerves and the communicating rami.

The difference between these two views may be accounted for in part by fundamental differences in the morphogenesis of the sympathetic nervous system in the various classes of vertebrates. 


close proximity with each other that the entire anlage of the sympathetic trunk appears as a continuous cell-column. This cell-column is not of uniform diameter, but in transverse sections traces of it are not wanting in any section in the thoracic and the dorsal region. Fibers are not present as yet either in the anlagen of the sympathetic trunks or in the communicating rami. The sympathetic anlagen are essentially cellular. The cells are closely aggregated and many of them present delicate protoplasmic processes, or are included in small syncytia. These structures are not very apparent in transverse sections, but in sagittal or frontal sections the anlagen of the sympathetic trunks present the appearance of a loose-meshed cellular network.

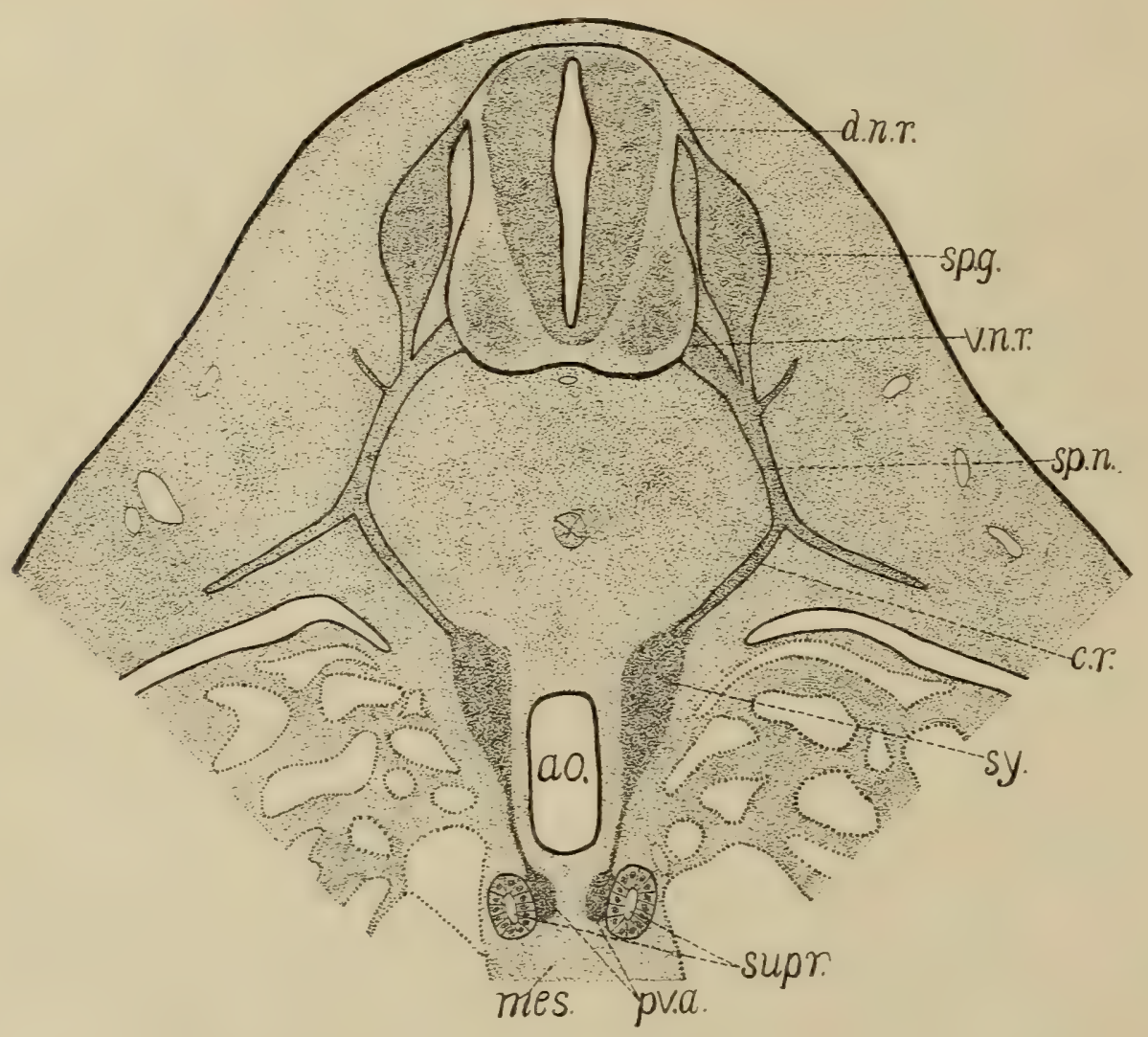

FIG. A. Diagrammatic transverse section of an embryo $12 \mathrm{~mm}$. in length through the suprarenal bodies, $\times 50$. 


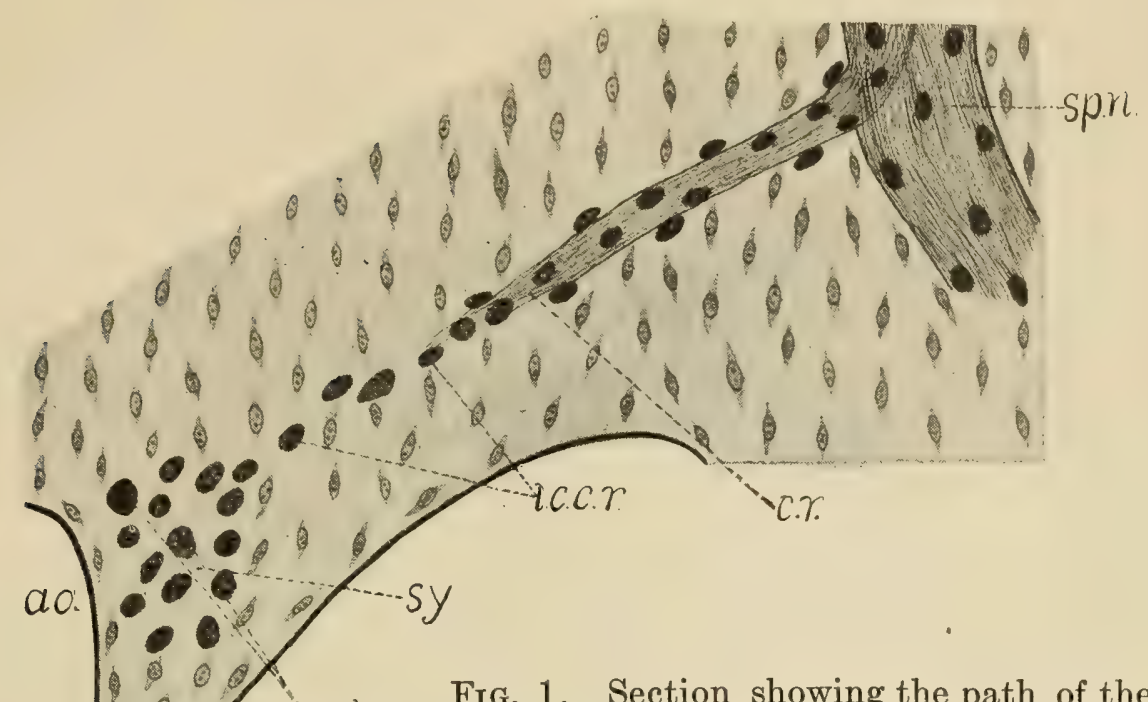

Frg. 1. Section showing the path of the communicating ramus in an embryo 9 in $\mathrm{mm}$. length, $\times 210$. (See reference letters below.)

\section{REFERENCE IETTERS OF FIGURES \\ (Except Fig. 16)}

All of the figures were drawn with the aid of the camera lucida or the projection lantern. A uniform scale of magnification was not adopted, but the scale of diameters of the drawing as reproduced is given in the description of each figure.

a.i.c.-Accompanying indifferent cells. ao.-Aorta.

b.rec.-Branch of recurrent nerve.

ca.-Carotid artery.

car.n.-Cardiac nerves.

car.b.-Anlagen of cardiac plexus.

c.r.-Communicating ramus.

c.m.d.n.r.-Cells migrating into dorsal nerve-root.

c.m.pv.-Cells migrating from sympathetic trunks into prevertebral plexuses.

c.m.v.r.-Cells migrating into ventral nerve-root.

c.m.vag.r.-Cells migrating into vagus rootlets.

d.n.r.-Dorsal nerve-root.

e.l.m.-External limiting membrane.

f.pv.-Fibers extending into prevertebral plexuses.

g.c.-Germinal cells of His.

i.c.c.r.-Indifferent cells in communicating ramus.
i.l.m.-Internal limiting membrane.

mes.-Mesentery.

m.r.f.-Motor root-fibers.

m.s.p.-Anlage of myenteric and submucous plexuses.

$n b .-$ Neuroblasts

oe.-Asophagus.

o.rec.n.-Origin of recurrent nerve.

p.a.-Pulmonary artery.

pv.a.-Anlagen of prevertebral plexuses.

rec.n.-Recurrent nerve.

sp.g.-Spinal ganglion.

$s p . n$.-Spinal nerve.

s.r.f.-Sensory root-fibers.

supr.-Suprarenal bodies.

sy.-Anlagen of sympathetic trunks.

t.-Trachea.

vag.-Vagus trunk.

vag.b.-Branch of vagus nerve.

vag.r.-Rootlets of vagus nerve.

v.n.r.-Ventral nerve-root. 


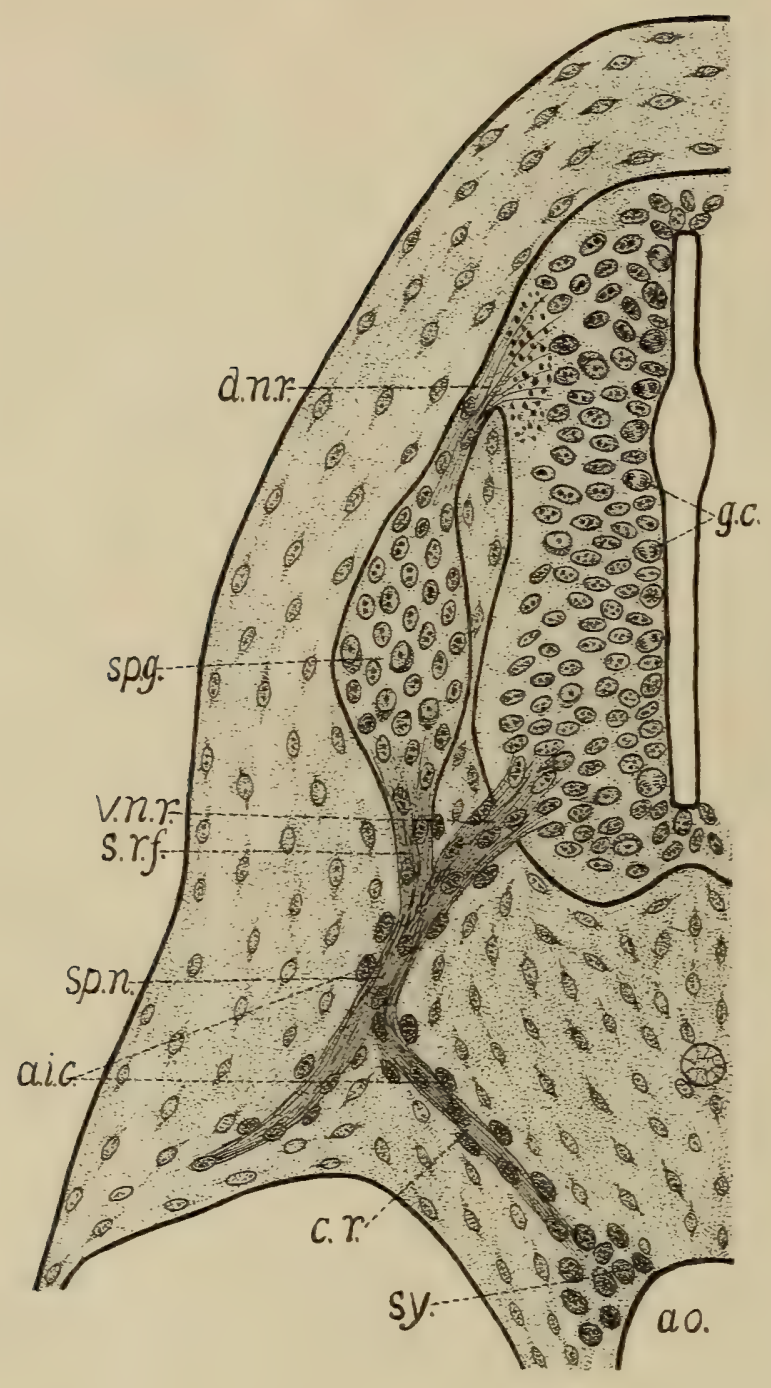

FIG. 4. Transverse section of the neural tube and the anlage of the sympathetic trunk of an embryo $11 \mathrm{~mm}$. in length, $\times 125$.

evidence of the migration of medullary cells from the neural tube is found in embryos about $4.5 \mathrm{~mm}$. in length. At this stage the neural crest is not yet differentiated into ganglia, but appears as an inconspicuous ridge spreading laterally from the median dorsal line of the neural tube. It is so inconspicuous indeed that in many sections it may be distinguished only under favorable conditions. In a few instances the fibers of the ventral nerve-roots have penetrated the walls of the neural tube and are accompanied 
by medullary cells which have broken through the external limiting membrane.

In embryos $7 \mathrm{~mm}$. in length, the spinal ganglia are distinct, but are not completely formed as yet, and have receded but a short distance from the point at which the fibers of the dorsal nerveroots enter the neural tube. In transverse sections, numerous breaches may be observed in the external limiting membrane in

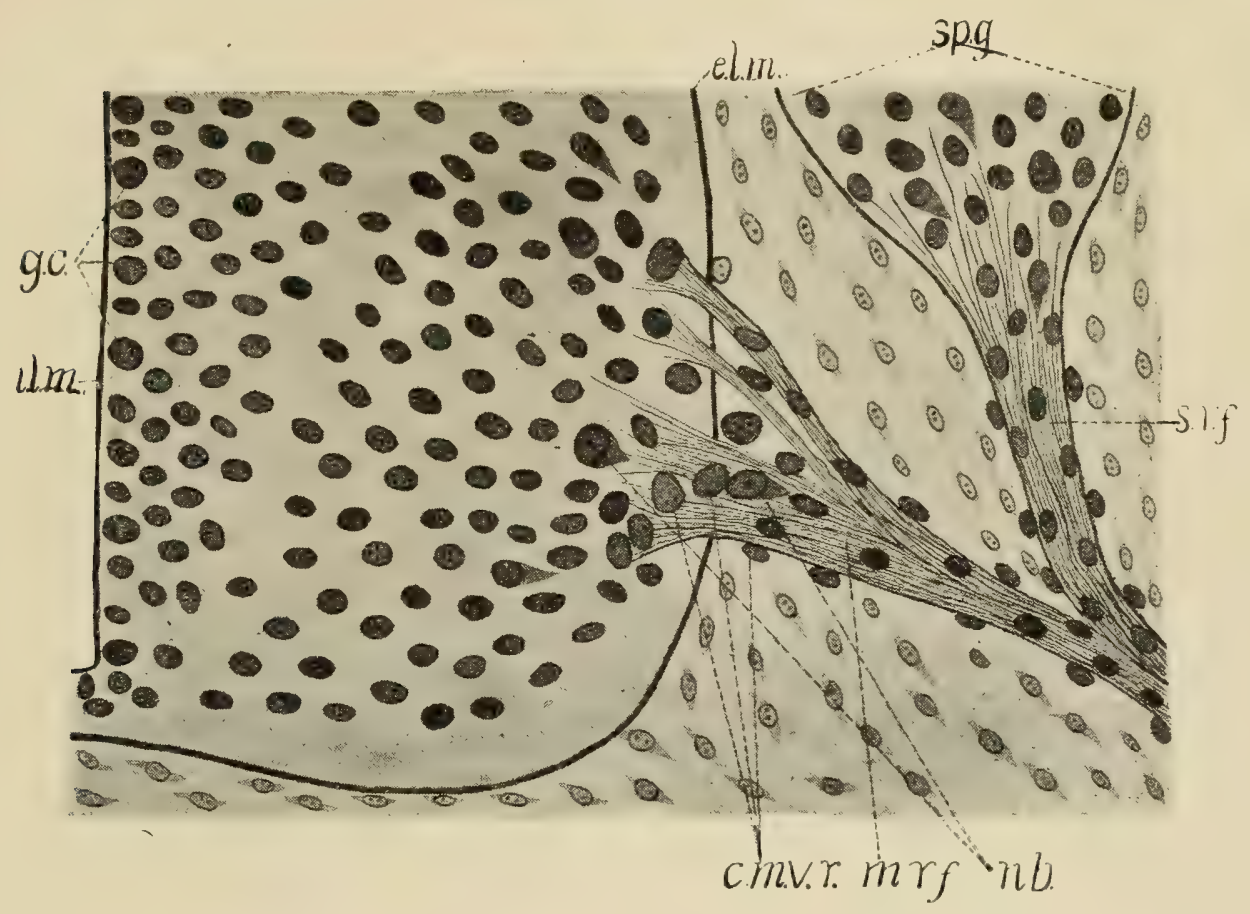

FIG. 5. Transverse section of the ventral part of the neural tube of an embryo $9 \mathrm{~mm}$. in length, showing cells migrating into the ventral nerve-root, $\times 250$.

the region of the dorsal nerve-roots. Rows of cells practically touching each other end to end may be traced from the mantle layer, through these breaches, into the proximal parts of the dorsal nerve-roots (fig. 3, c.m.d.n.r.). Further evidence for the migration of medullary cells into the dorsal nerve-roots is presented by the fact that in many sections where no breaches occur, cells are crowded close to the external limiting membrane in this region. In embryos $9 \mathrm{~mm}$. and over in length, this area is always 
zontal line represent the lengths of the embryos in $\mathrm{mm}$.; the figures in the vertical line indicate the number of cells present in a given length of longitudinal sections of the spinal nerves, as they appear in transverse sections of the embryos, taken at random between the point of union of the sensory and the motor roots and the origin of the communicating rami. Embryos which seemed to be most normal in their development were selected, and the curve is based on the averages of ten independent counts. This curve

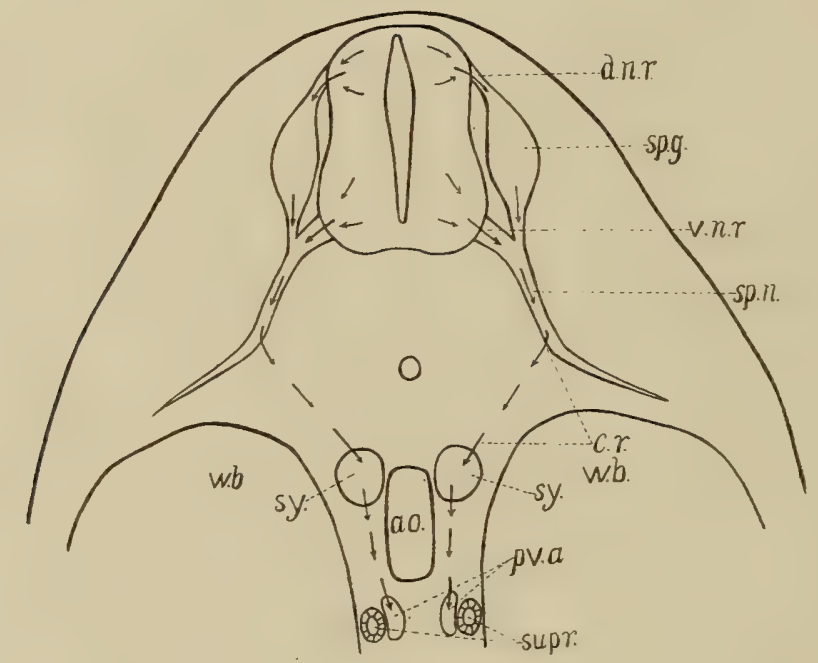

FIG. 7. Diagrammatic transverse section of an embryo 9 or $10 \mathrm{~mm}$. in length. The arrows indicate the course and the direction of the cells migrating from the neural tube and the spinal ganglia into the sympathetic anlagen.

ao., Aorta. c.r., Path of communicating ramus. d.n.r., Dorsal nerve-root. pv.a., Anlagen of prevertebral plexuses. sp.g., Spinal ganglion. sp.n., Spinal nerve. supr., Suprarenal bodies. sy., Sympathetic trunks. v.n.r., Ventral nerve-root. $w . b .$, Wolffian body.

indicates that the rate of migration reaches its maximum in embryos $9 \mathrm{~mm}$. in length, and that migration practically ceases when a length of $13 \mathrm{~mm}$. is attained. It also indicates that a relatively small but fairly constant number of cells remains in the spinal nerves after migration has ceased.

As already indicated in reviewing the literature, Kohn and Neumayer have attempted to account for the cells giving rise to the sympathetic nervous system, by local differentiation of elements 
already present in the sensory and the motor nerve-roots. This view seems to be quite generally accepted by the advocates of the theory of local differentiation and the multicellular nature of nerve-fibers. These two conceptions obviously go hand in hand. It is not the writer's purpose to discuss the nature of nerve-fibers. Suffice it to say that in the light of the recent investigations of Cajal, Harrison, and others, the neurone theory

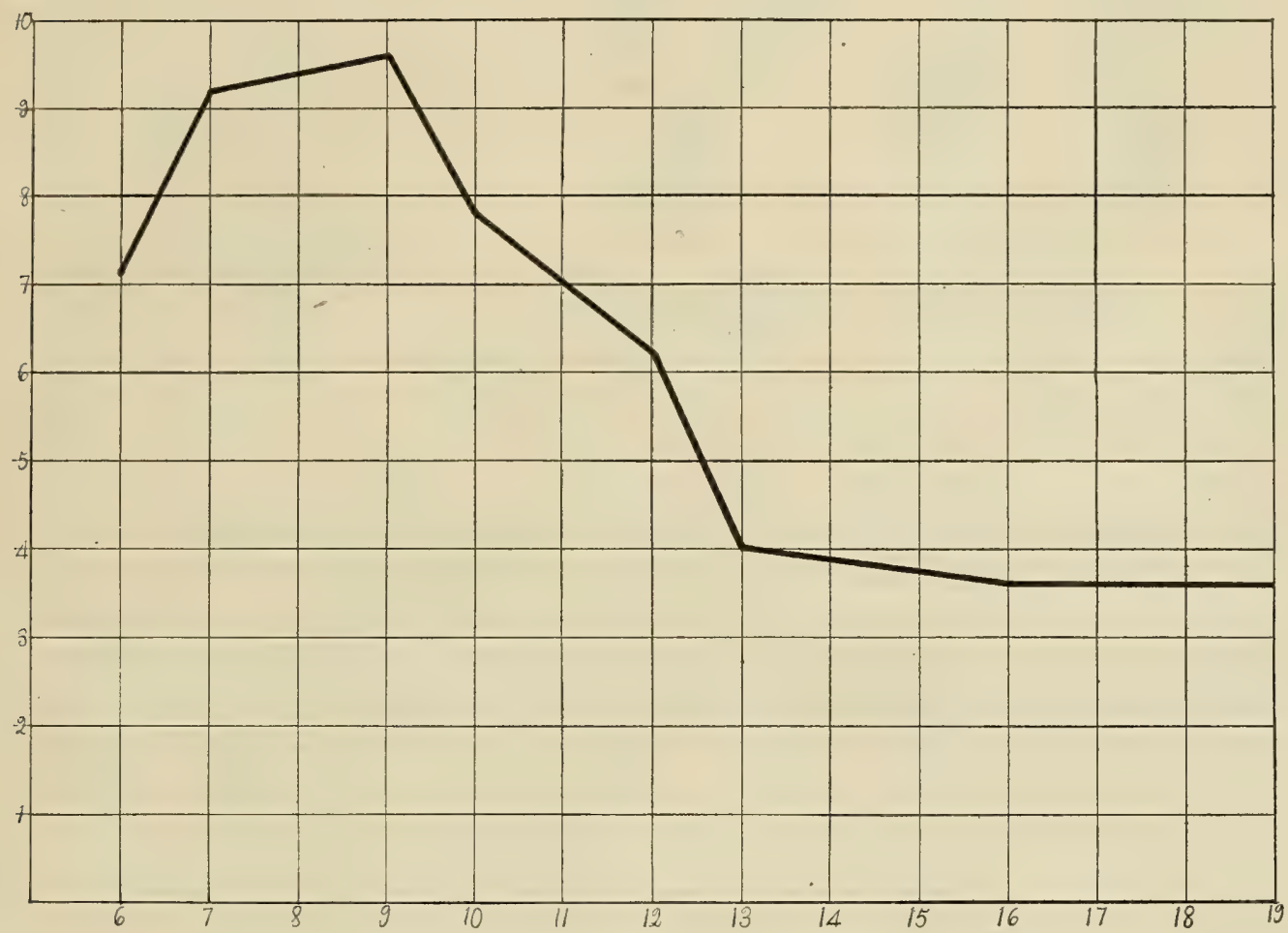

FIG 8. Curve designed to indicate the relative rate of migration of cells from the neural tube and the spinal ganglia along the spinal nerves, in successive stages of development. For explanation see text.

seems to be firmly established. On the other hand, if the "accompanying" cells do not migrate peripherally we cannot account for the rapid decrease in the number of such cells present in the proximal part of the spinal nerves, which, as shown in fig. 8, takes place in embryos from 9 to $13 \mathrm{~mm}$. in length. Mitotic figures occur occasionally in the nerve-roots as well as in the nerve-trunks and in the communicating rami. Doubtless, many 
of the "accompanying" cells arise by the mitotic division of "indifferent" cells along the course of migration, but these mitotic figures are by no means sufficiently numerous to account for the multitudes of cells which take part in the development of the sympathetic trunks. Furthermore, I have observed cells along the spinal nerves and the communicating rami, which, as will be shown later, are neuroblasts. Such cells were recently described by Cajal ('08) in the spinal nerves, and the communicating rami in embryos of the chick. According to Cajal, "these neuroblasts do not correspond to the neurocytes of Kohn, but to the real motor cells in the neural tube." These facts are incompatible with the theory of local differentiation.

(c) Later development.-In embryos $12 \mathrm{~mm}$. in length, the anlagen of the sympathetic trunks are rapidly becoming fibrous. They still appear as continuous cell-columns showing little evidence of their future segmental character. The earliest fibers of the longitudinal commissures, therefore, do not grow out through the inter-gangliar spaces, but the cells become aggregated into distinct ganglia after the sympathetic trunks have become fibrous. "Accompanying" cells are still present along the spinal nerves and the communicating rami, but they are notably fewer than in the preceding stages. Cells may still be observed migrating from the neural tube and the spinal ganglia, but such migration probably does not continue far beyond this stage. In embryos over $12 \mathrm{~mm}$. in length, the motor niduli are sharply limited, and medullary cells are rarely seen along the fibers of the ventral nerveroots as they traverse the marginal veil. The spinal ganglia are also becoming more sharply limited distally, and cells no longer become separated from them. The later development of the sympathetic trunks consists in progressive changes and growth of the elements already present.

(d) Nature of migrating cells. - In his excellent work on the earliest differentiations in the central nervous system, Schaper ('97) made a most thorough and detailed study of the cells which arise by the mitotic division of the "germinal" cells (Keimzellen) of His. These cells were originally described by His as cells 


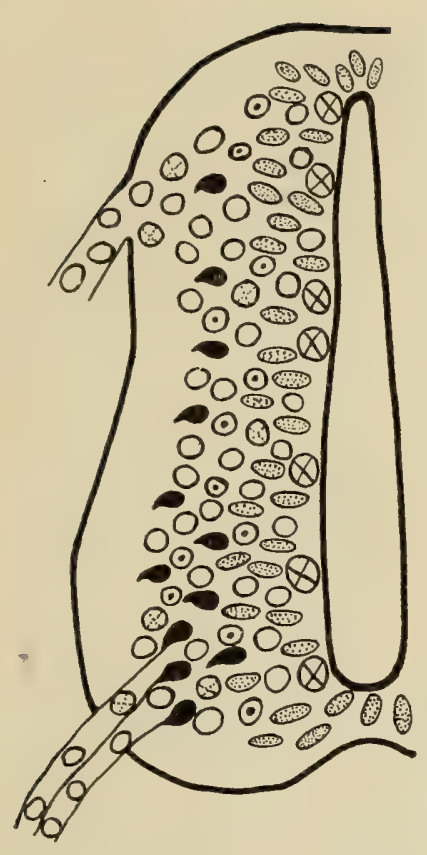

FIG. 9

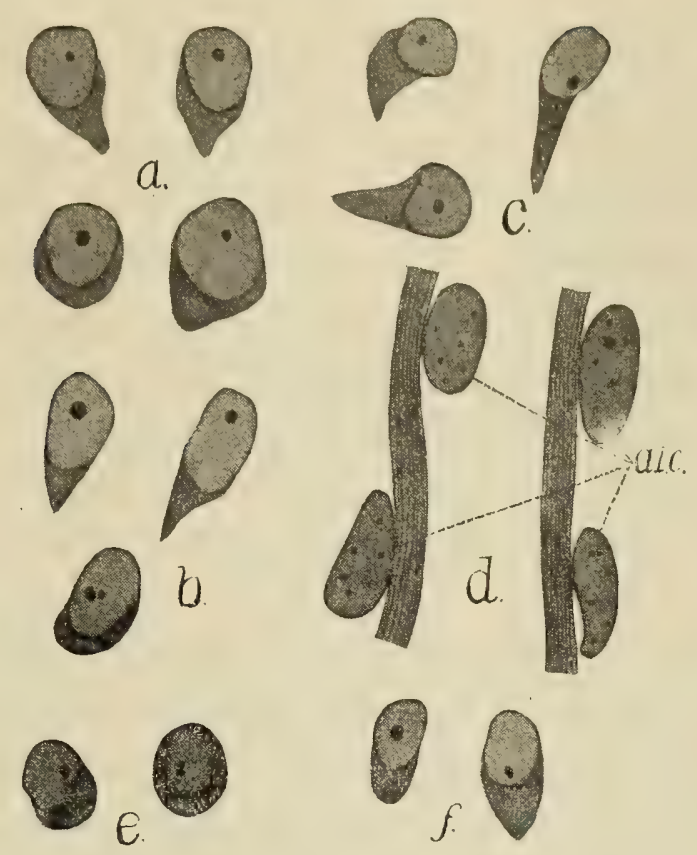

FIG. 10

FrG. 9. Diagram illustrating the developmental relationships of the neuroblasts and the embryonic supporting cells in the neural tube of mammalian embryos (modified from Schaper, '97). Elongated dotted cells = ependymal cells; large circular cells with crosses $=$ germinal cells of His $;$ plain rounded cells $=$ indifferent cells; rounded cells with dotted .crosses $=$ indifferent cells which undergo further division by mitosis; rounded cells with dots in center = neuroglia cells; block cells $=$ nerve cells.

FIG. 10. Ganglion cells, neuroblasts, and indifferent cells, $\times 1100 . a_{.}$, Cells in the spinal ganglia. $b .$, Neuroblasts in the ventral nerve-roots. $c$., Neuroblasts in the spinal nerve trunks. $d$., Bundles of fibers with accompanying indifferent cells, from the spinal nerves. $e$., Neuroblasts in the communicating ramus. $f$., Neuroblasts in the anlagen of the sympathetic trunks.

of ectodermal origin undergoing mitotic division near the internal limiting membrane of the embryonic neural tube, giving rise to cells which develop into neuroblasts. Schaper has shown that the cells arising by the mitotic division of the "germinal" cells of His do not all develop into neuroblasts. They are cells of an indifferent character. In the lower vertebrates they are transformed either into neuroblasts or into embryonic supporting cells. In the higher vertebrates, however, many of these "indifferent" cells retain a capacity for further propagation by di- 
vision and give rise to new generations of "indifferent" cells which may develop either into neuroblasts or into embryonic supporting cells. The accompanying figure (fig. 9), modified from Schaper, has been introduced to illustrate the developmental relationships of the neurones and the supporting elements in the embryonic nervous system. According to Schaper's original description, the "indifferent" cells are characterized by large rounded nuclei showing a delicate chromatin structure, and very little cytoplasm. The "neuroblasts" are characterized by large rounded nuclei showing little structure in the interior except a well defined nucleolus, and a larger cytoplasmic body which is early drawn out to a point at one side.

The great majority of the cells migrating from the neural tube and the spinal ganglia, along the spinal nerves and the communicating rami in embryos of the pig, answer to the description of the "indifferent" cells of Schaper. When observed in the motor niduli or in the distal ends of the spinal ganglia, their nuclei usually appear more or less rounded in outline and show a very delicate chromatin structure. The cytoplasm is so meager that it can be observed only under the most favorable conditions. As these cells migrate peripherally they assume a more elongated form. In the ventral nerve-roots many of them have assumed their maximum elongation soon after they have left the neural tube. In the lines of cells which may be observed migrating out of the neural tube, the inner ones are often nearly circular in outline, the outer ones are greatly elongated, while those in intermediate positions show varying degrees of elongation. This elongation cannot be accounted for mechanically, as by the squeezing through a narrow aperture in the external limiting membrane. These apertures are usually broad enough to permit free passage of the cells. It is probably due to more subtle forces which are operative in the process of migration. Furthermore, it is by no means certain that such a change of shape always takes place. Rounded "indifferent" cells are sometimes observed far distally along the course of migration, while elongated cells are present in the motor niduli and in the distal ends of the spinal ganglia. 
Among the "indifferent" cells of Schaper, cells are occasionally found which are characterized by large rounded or elongated nuclei showing a well defined nucleolus and very little chromatin structure, and a considerable quantity of cytoplasm which is usually drawn out to a point at one side (fig. 10). These cells are obviously the "neuroblasts" of Schaper. They are few in number, but occur all along the path of migration of the sympathetic cells. I have observed them in the ventral nerve-roots both inside and outside the external limiting membrane, in the spinal nerves, in the communicating rami, and in the anlagen of the sympathetic trunks.

The histogenetic relationships of the cells taking part in the development of the sympathetic trunks will be considered further in section $\mathrm{V}$. The facts of importance at this point are that cells which are endowed with a capacity to develop into neurones, migrate peripherally from the neural tube and the spinal ganglia, and that some of these cells migrate into the anlagen of the sympathetic trunks. These facts establish a direct genetic relationship between the sympathetic and the central nervous system. We are not to suppose, however, that all the cells taking part in the development of the sympathetic trunks actually migrate as such from their sources in the neural tube and the spinal ganglia. Doubtless, many arise by the mitotic division of "indifferent" cells along the course of migration. The sources of these migrating elements are, therefore, sufficient to account for all the cells which take part in the development of the sympathetic trunks and the sympathetic plexuses genetically related to them.

\section{PREVERTEBRAL PLEXUSES}

(a) Development.- In embryos $10 \mathrm{~mm}$. in length, the anlagen of the prevertebral plexuses may be recognized as small cellaggregates lying along the ventro-lateral surfaces of the aorta in the dorsal and the lumbar regions. In these regions the sympathetic trunks are not sharply limited ventrally. Cells become separated from their ventral margins and migrate ventrally along the sides of the aorta (fig. 11, c.m.pv.). In the region of the 
suprarenals, such cells hare descended as far as the mesial surfaces of these bodies which. at this time, appear as compact cellcolumns more or less circular in transverse section, lying parallel with the aorta a short distance from its ventro-lateral surfaces (fig. 11, supr.). Posterior to the suprarenals, small cell-aggregates are present all along the rentro-lateral surfaces of the aorta as far as the origin of the iliac arteries. It is impossible, in this stage, to determine the limits of the anlagen of the sereral srm-

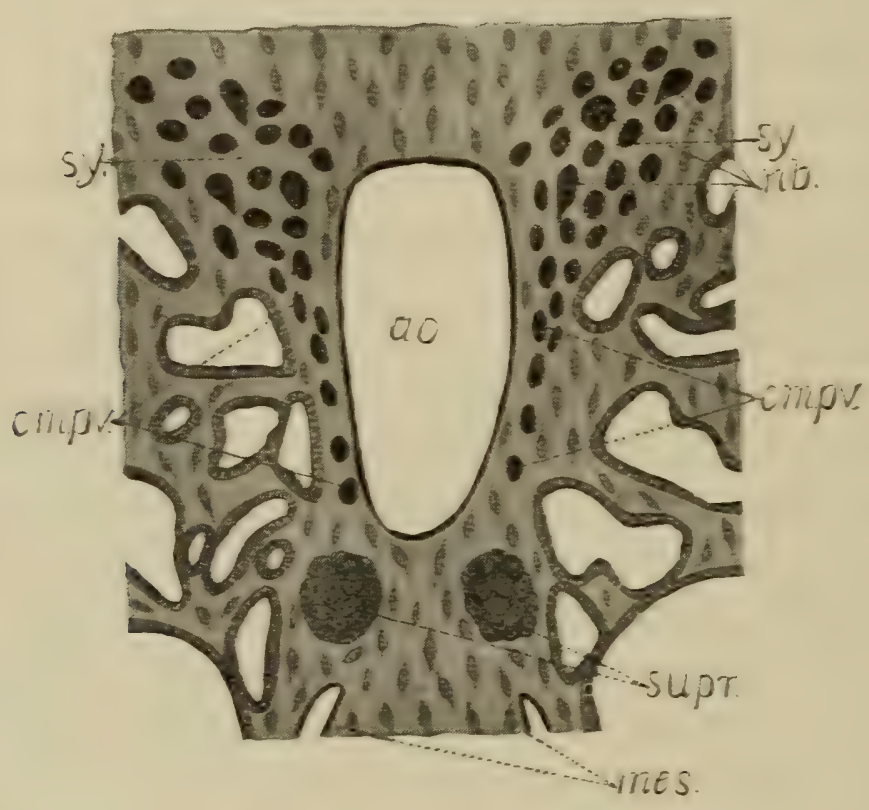

FIG. 11. Transverse section through the sympathetic trunks and the suprarenal bodies of an embryo $9 \mathrm{~mm}$. in length, $\times 150$.

pathetic plexuses in this region. The only distinction between the cell-aggregates which constitute the anlagen of the cœliac, the renal, the abdominal aortic, and the hypogastric plexuses consists in a difference in degree of development. Development proceeds somewhat more rapidly in the anterior than in the posterior region. In transverse sections through this region, traces of one or the other of these plexuses appear in nearly every section. 
In embryos $13 \mathrm{~mm}$. in length, the cell-aggregates lying along the ventro-lateral surfaces of the aorta have become more pronounced. The greatest development occurs in the region of the suprarenals. At a few points, fibers may be traced from the sympathetic trunks into the anlagen of the prevertebral plexuses (fig. 12, f.pv.). In the region of the coliac plexus, fibers have advanced farther peripherally and may be traced for a short distance into the mesentery. The anlagen of the abdominal aortic plexus have developed into a loose network which completely surrounds the aorta ventrally.

In embryos $16 \mathrm{~mm}$. in length, the prevertebral plexuses are becoming more distinct and more fibrous. The sympathetic trunks are more sharply limited ventrally, except in the region of the suprarenals. At this point there is still a continuous line of sympathetic cells extending from the sympathetic trunks into the cell-aggregates associated with the suprarenals.

(b) Histogenetic relationships.-The cells constituting the anlagen of the prevertebral plexuses show all the characters of the cells present in the sympathetic trunks. Continuous lines of cells may be traced from the latter into the former. The prevertebral plexuses, therefore, stand in direct genetic relationship to the sympathetic trunks. Mitotic figures occur occasionally along the courses of migration from the sympathetic trunks as well as in the anlagen of the prevertebral plexuses. Doubtless, a goodly number of the cells taking part in the development of the prevertebral plexuses arise by the mitotic division of "indifferent" cells along the courses of migration. The development of the prevertebral plexuses is, therefore, entirely analogous with the development of the sympathetictrunks.

\section{VAGAL SYMPATHETIC PLEXUSES}

(a) Introductory.-Under the term vagal sympathetic plexuses, we shall consider those plexuses, usually regarded as sympathetic, which are directly related to the vagi; viz., the cardiac plexus and the sympathetic plexuses in the walls of the vvisceral organs. 


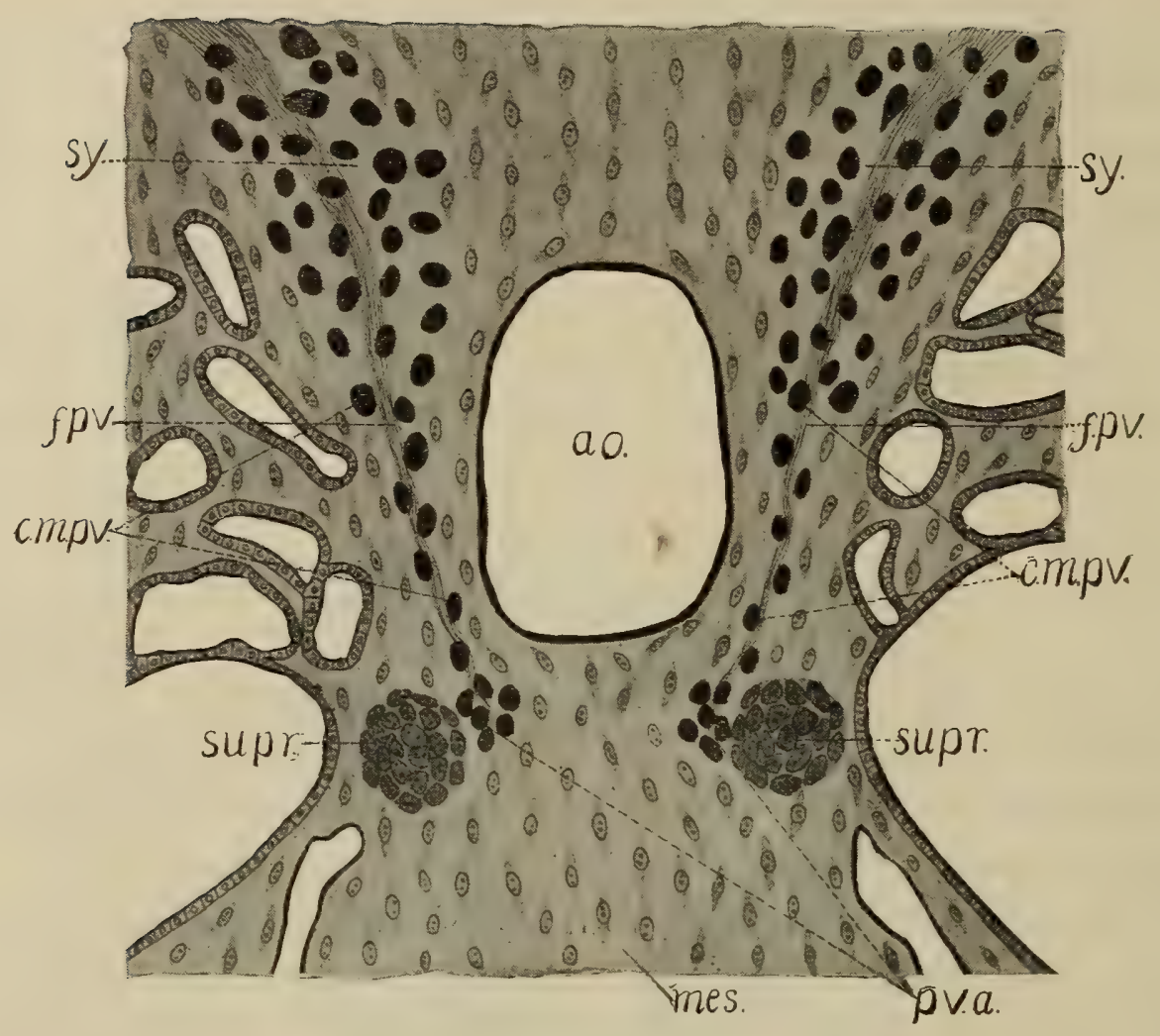

FIG. 12. Transverse section through the sympathetic trunks and the anlagen of the cœliac plexus of an embryo $12 \mathrm{~mm}$. in length, $\times 150$.

Our knowledge concerning the development of the sympathetic plexuses related to the vagi is very limited. The older workers generally gave little attention to the peripheral sympathetic plexuses. Onodi ('86), though he traced the origin of the sympathetic trunks and the prevertebral plexuses to the spinal ganglia, could not derive the peripheral sympathetic plexusesfrom the same source, because he found no cellular connections between the latter and the sympathetic trunks. He believed it necessary, therefore, to cling to the doctrine of Remak ('47) with regard to the peripheral sympathetic plexuses and derive them from the mesoderm. His, Jr., ('91) traced the origin of the peripheral sympathetic plexuses, including the sympathetic plexuses in the walls of the digestive tube and the sympathetic components related to the vagi, to cell-swarms which migrate peripherally from the anlagen of the sympathetic trunks. 
Later writers have generally assumed that the cardiac plexus and the sympathetic plexuses in the walls of the visceral organs have their origin in the sympathetic trunks, but the course of tbeir development has not been made clear. The literature bearing on this point is conspicuously meager.

My own observations, as indicated in a recent paper, ${ }^{2}$ have shown that the cardiac plexus and the sympathetic plexuses in the walls of the visceral organs do not owe their origin to the sympathetic trunks as has hitherto been supposed, but that they arise from cells which migrate from the vagus ganglia and the walls of the hind-brain along the fibers of the vagi.

Because the origin of these plexuses is distinct and separate from the origin of the sympathetic trunks and the sympathetic plexuses described above as prevertebral plexuses, they cannot properly be characterized as prevertebral sympathetic plexuses. In view of their relation to the vagi I have chosen to designate them as vagal sympathetic plexuses. The term "vagal sympathetic" is a departure from the established nomenclature, but inasmuch as there is no good collective term which could be applied to the cardiac plexus and the sympathetic plexuses in the walls of the visceral organs, it has seemed well, for the sake of clearness, to employ a new term.

(b) Myenteric and submucous plexuses.-In transverse sections of embryos 6 and $7 \mathrm{~mm}$. in length, in the region of the œesophagus, the vagus trunks appear as large bundles of loosely aggregated fibers accompanied by numerous rounded or elongated cells. These cells, which, as will be shown later, are of medullary and ganglionic origin, are easily distinguished from the cells of the surrounding mesenchyme by their larger size and the characteristic chromatin structure of their nuclei. Many of them appear to become separated from the nerve-trunks and to wander into the walls of the œsophagus until the latter is completely surrounded by these migrant cells. In a few sections short fibers are seen to bend from the vagus trunks toward the œsophagus (fig. 13, vag.

${ }^{2}$ The rôle of the vagi in the development of the sympathetic nervous system. Anatomischer Anzeiger, Bd. 35, no. 15, 16, pp. 381-390. 
b.). From the tips of these growing fibers, cells pass in well defined paths into the walls of the œsophagus. It is probable that most of the cells which become separated from the vagi wander out along the fibers of these growing branches. The cells which have wandered into the walls of the osophagus are not arranged in well defined rings as yet, but are loosely scattered in the tissues (fig. 13, m.s.p.).

The fibers of the vagi do not yet extend beyond the region of the heart. In transverse sections through the stomach, the paths of the vagus branches are indicated by the presence of numerous

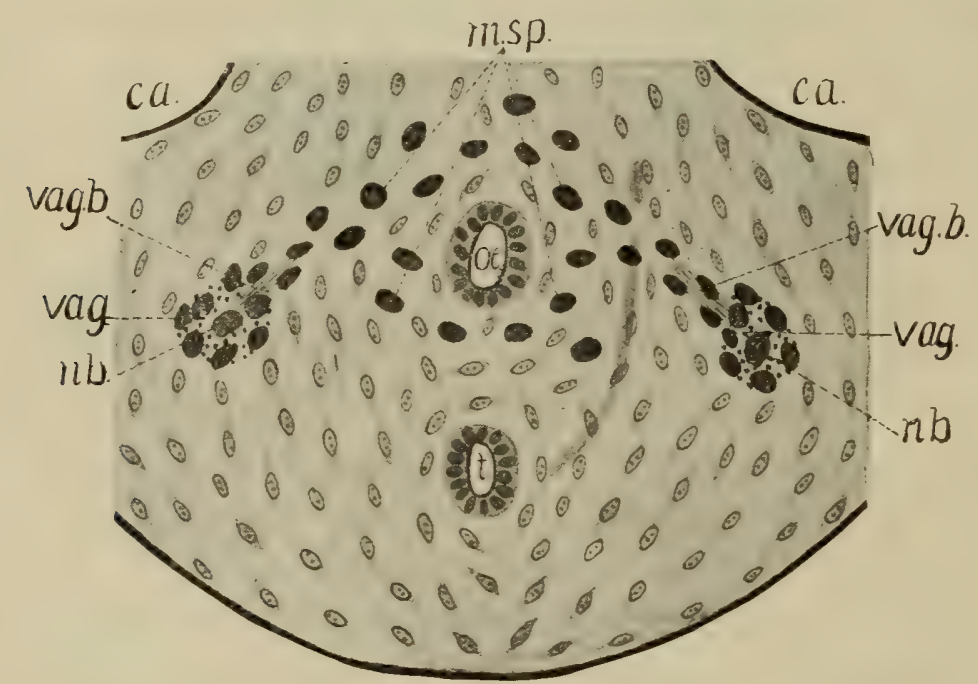

Fig. 13. Transverse section through the œsophagus and the vagus trunks in an embryo $7 \mathrm{~mm}$. in length, $\times 160$.

cells like those described above. These cells show a tendency to spread until they have completely surrounded the walls of the stomach. Similar cells are found scattered in the walls of the intestine as far as the latter can be traced. Thus, it appears that, having once become established in the anterior region of the digestive tube, these cells migrate posteriorly along its course.

That these migrant nervous elements found in the walls of the digestive tube have migrated thither from the vagus trunks cannot be doubted. There is no difficulty in tracing cells from the 
tips of the growing branches of the vagi into the walls of the œesophagus. Furthermore, it is impossible to trace cells from any other source. There is no evidence as yet of the migration of cells from the sympathetic trunks or from the prevertebral plexuses toward the walls of the digestive tube. Neither cellular nor fibrous connections occur between the sympathetic trunks or the prevertebral plexuses and the sympathetic plexuses in the walls of the digestive tube until the latter have become well established.

In transverse sections of embryos $9 \mathrm{~mm}$. in length, there is no evidence of cells wandering from the vagus trunks toward the œsophagus except along the fibers of the growing branches. These courses are still plainly visible. The migrant cells in the walls of the œsophagus have become arranged in more definite rings, and none are found scattered in the surrounding tissue. Numerous cells still accompany the fibers of the vagi all along their course and seem to escape freely at their growing tips.

In embryos $12 \mathrm{~mm}$. in length; the number of cells in the proximal part of the vagus trunks has materially decreased. Most of those still remaining probably subserve a supporting function. The more distal parts still contain numerous cells. It is probable, however, that the migration of cells along the vagi does not continue far beyond this stage. In the region just anterior to the stomach, the vagus trunks have broken up into a loose network which is the beginning of the œsophageal plexus. Vagus fibers still accompanied by numerous cells may now be traced along the lesser curvature of the stomach. The anlagen of the cœliac plexus are well established, but there are no fibrous connections as yet between them and the anlagen of the sympathetic plexuses in the walls of the digestive tube.

In embryos $16 \mathrm{~mm}$. in length, the vagus trunks as well as their branches, many of which have established connections with the myenteric and the submucous plexuses, are apparently free from migrating cells. In the walls of the œsophagus, the cells which have wandered in are aggregated into more or less distinct groups arranged in two broken rings. The myenteric and the submucous plexuses are thus becoming distinct. A similar arrangement, though less definite, is apparent also in the walls of the intestine. 
Fibrous connections have become established with the sympathetic trunks as well as with the cœliac and the hypogastric plexuses. It is interesting to note that all these sympathetic nerves still contain numerous "accompanying" cells which are apparently migrating peripherally along their fibers. It is probable. therefore, that cells wander down from the sympathetic trunks into the mrenteric and the submucous plexuses after these fibrous connections are established.

(c) Pulmonary plexuses.-In transverse sections of embryos 6 or $7 \mathrm{~mm}$. in length, some of the cells which wander from the vagus trunks toward the œsophagus, in the region of the bifurcation of the trachea, are carried out along the anterior and the dorsal surfaces of the bronchi. These cells obviously give rise to the anlagen of the pulmonary plexuses.

(d) Cardiac plexus.-The first unmistakable evidence of ganglia pertaining to the cardiac plexus is found in embryos about 12 $\mathrm{mm}$. in length. In transverse sections through the anterior region of the heart, small groups of nervous elements are observed ventral to the trachea (fig. 14 , car.p.), a few of which have penetrated deep into the angle between the aorta and the pulmonary artery. These cell-aggregates constitute the anlagen of the earliest ganglia of the cardiac plexus. They are without fibrous connections as yet. but a few short fibrous branches are seen to arise from the ragus trunks and the left recurrent nerve, which extend toward the heart fig. 14, carn). These are obviously the earliest cardiac nerves. Their fibers are still loosely aggregated and are accompanied by numerous cells, some of which appear to escape at the tips of the nerves and to migrate toward the cardiac ganglia in adrance of the groming fibers. Nertes cannot be traced as yet from the sympathetic trunks toward the heart, and there is no evidence of the migration of cells from the sympathetic trunks into the anlagen of the cardiac plexus.

In embryos $16 \mathrm{~mm}$. in length, branches of the ragi as well as cardiac nerves having their origin in the sympathetic trunks may be traced into the ganglia of the cardiac plexus. Here again it is interesting to note that while the branches of the ragi are apparently free from migrating cells, the cardiac nerves having their 


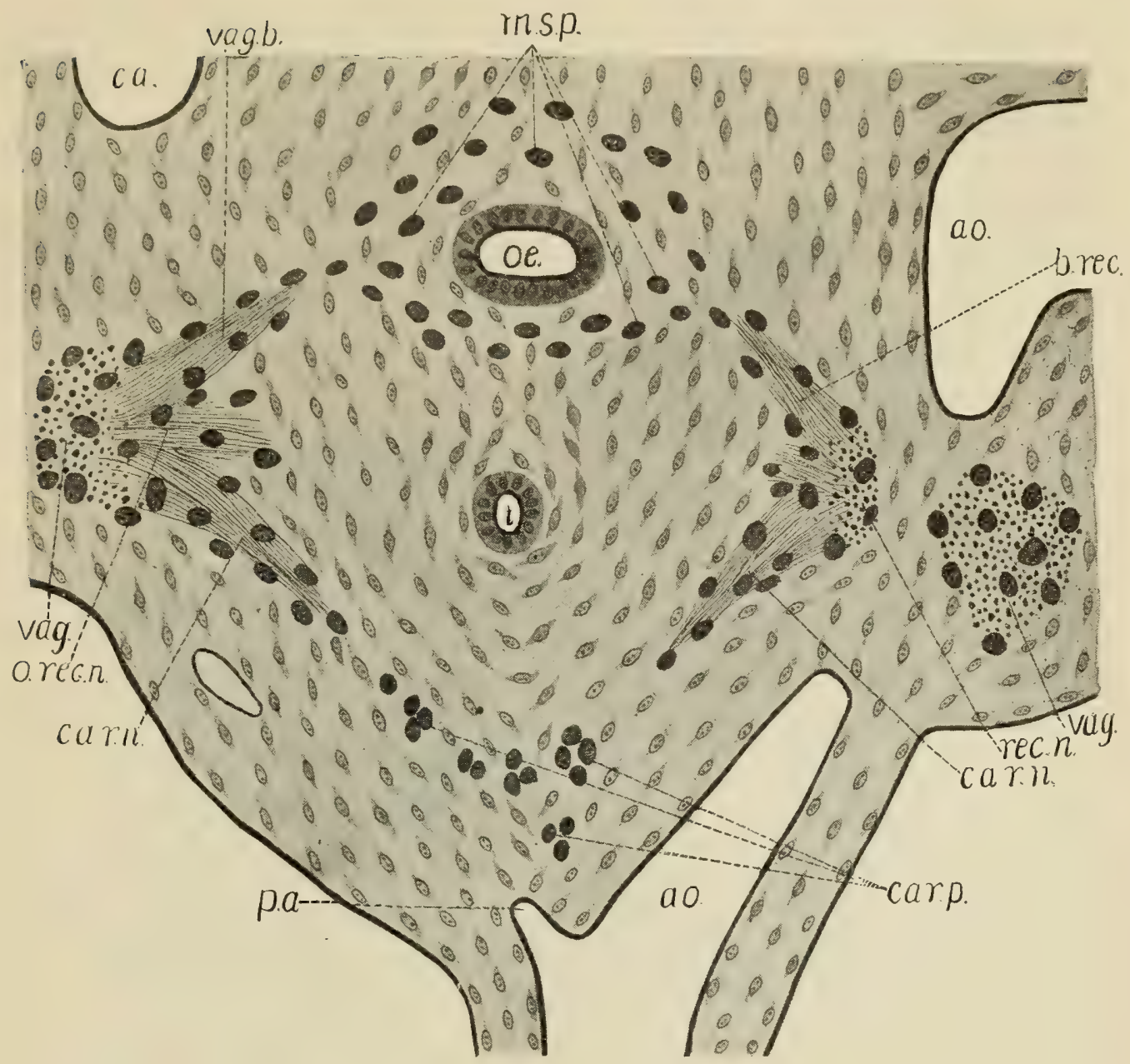

Fig. 14. Transverse section through the oesophagus, the vagus trunks, and the anlagen of the cardiac plexus in an embryo $13 \mathrm{~mm}$. in length, $\times 100$.

origin in the sympathetic trunks still contain numerous "accompanying" cells which are apparently migrating peripherally along their fibers. It is probable, therefore, that the cardiac plexus also receives cells from the sympathetic trunks after the sympathetic cardiac nerves have become established.

This stage in the pig may be compared with the human embryo $10.2 \mathrm{~mm}$. in length described by His, Jr. ('91). He also observed that, in this stage, the branches of the vagi are comparatively free from cells, while the carciac nerves having their origin in the sympathetic trunks contain many cellular elements. He con- 
cluded, therefore, that the ganglia of the cardiac plexus are composed exclusively of cells which have migrated thither from the sympathetic trunks.

The above observations prove conclusively that the earliest anlagen of the cardiac plexus in the pig arise from cells which migrate thither from the vagus trunks. This is probably true for all mammals. In the human embryo of His, Jr., referred to above, the cardiac plexus already had fibrous connections with both the vagi and the sympathetic trunks. The anlagen of the cardiac plexus would probably have been found considerably earlier.

My observations on the later development of the cardiac plexus in the pig do not differ essentially from those of His, Jr., ${ }^{3}$ on the human embryo, except that the earliest cardiac nerves having their origin in the sympathetic trunks are less intimately associated with the vagi, and enter the cardiac plexus independently. This fact was also observed by His, Jr., in embryos of the cat.

(e) Cell migration along the vagi.--In sections taken at right angles to the axis of the trunk, in the head region of embryos 9 or $10 \mathrm{~mm}$. in length, medullary cells may be observed migrating from the walls of the hind-brain into the rootlets of the vagus and the spinal accessory nerves (fig. 15, c.m.vag.r.). That these cells wander out in considerable numbers cannot be doubted. In many sections medullary cells are observed drawn out into coneshaped heaps in the nerve-rootlets as they traverse the marginal veil. Occasionally one of these cells is observed half in and half out of the neural tube, and many are present in the nerve-rootlets just outside the external limiting membrane.

In sagittal sections the entire vagus trunk is seen to contain many of these "accompanying" cells which are apparently migrating peripherally. The ganglion of the trunk is, at this stage, a somewhat irregular oval or elliptical body which is not sharply limited distally. Cells appear to become separated from its distal end and to wander peripherally along the vagus trunk. Mi-

${ }^{3}$ Abhdl. Math-physischen Classe d. Königl. Sächs. Gesell.d. Wiss. Bd. 8, Leipzig 1891. 
totic figures occur frequently in the ganglion of the trunk and occasionally all along the vagus nerve.

The course and the direction of the cells migrating peripherally along the fibers of the vagi are indicated by the arrows in fig. 16 . That these cells actually migrate peripherally cannot be doubted. The number of "accompanying" cells present in the vagus trunks increases rapidly until a maximum number is reached in embryos 9 or $10 \mathrm{~mm}$. in length; then it decreases rapidly until the embryos

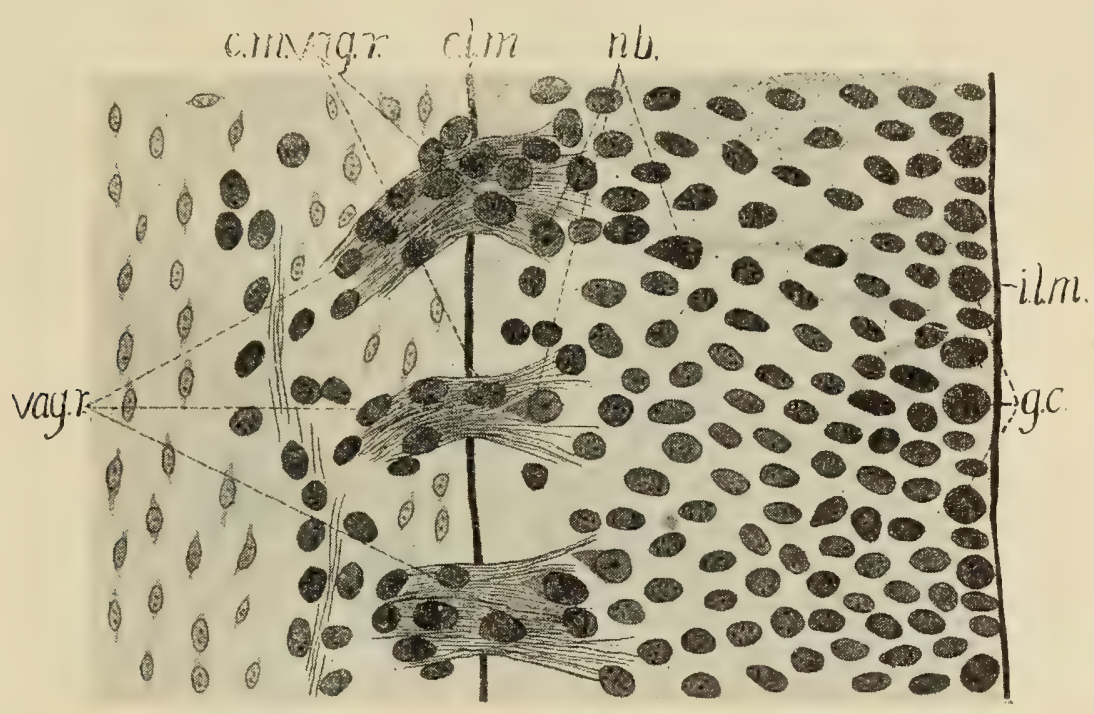

FIG. 15. Section through the rootlets of the vagus nerve in an embryo 10 $\mathrm{mm}$. in length, taken at right angles to the axis of the trunk, $\times 270$.

have attained a length of about $13 \mathrm{~mm}$., when only a relatively small number of cells remains distributed along the nerve-fibers. These phenomena can be explained on no other ground. Again, the preparations studied show figures of cells escaping from the growing branches of the vagi into the anlagen of the cardiac plexus and the sympathetic plexuses in the walls of the visceral organs which are perfectly clear, and can be interpreted only to mean that these are the cells which give rise to the vagal sympathetic plexuses.

The majority of the cells migrating peripherally along the fibers of the vagi are characterized by large rounded or elongated nuclei showing a delicate chromatin structure, and very little cytoplasm. 
These are obriously the "indifferent" cells of Schaper. Among these, other cells occasionally are found which are characterized by large rounded or elongated nuclei showing a well defined nucleolus and very little chromatin structure, and a larger crtoplasmic body which is usually drawn out to a point at one side (fig. 17). These cells are obviously the "neuroblasts" of Schaper. From this description it is obrious that the cells which migrate from

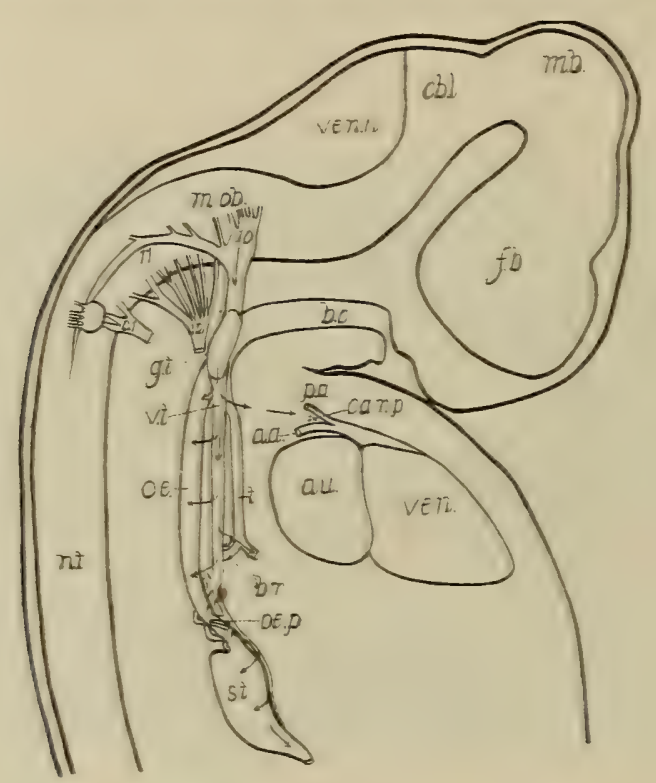

FIG 16. Diagram designed to show the relation of the vagi to the vagal sympathetic plexuses. The arrows indicate the course and the direction of the cells migrating from the walls of the hind-brain and the vagus ganglia into the anlagen of the vagal sympathetic plexuses.

a.a., Aortic arch. au., Auricle. b.c., Buccal cavity. br., Bronchi. car p., Anlagen of cardiae plexus. cb.l., Cerebellum. f.b., Fore-brain. g.t., Ganglion of the trunk. m.b., Mid-brain. m.ob., Medulla oblongata. n.t., Neural tube. oe., Esophagus. oe.p., Esophageal plexus. p.a., Pulmonary artery. st., Stomach. t., Trachea. ven., Ventricle. ven. IV., Fourth ventricle. v.t., Vagus trunk. 10., Roots of ragus nerve. 11., Roots of spinal accessory nerve. 12., Roots of hypoglossal nerve. r.I., First cervical nerve.

the ragus ganglia and the walls of the hind-brain along the ragi are cells of the same character as those which migrate from the neural tube and the spinal ganglia along the spinal nerres.

The above observations prove conclusively that the myenteric and the submucous plexuses, the pulmonary plexuses, and the 
cardiac plexus have a common origin which is distinct and separate from the origin of the sympathetic trunks. They arise from cells which have their origin in the vagus ganglia and the walls of the hind-brain. As in the case of the sympathetic trunks, however, we are not to suppose that all the cells taking part in the development of the vagal sympathetic plexuses actually migrate as such from their sources in the cerebro-spinal nervous system. Doubtless, many arise by the mitotic division of "indifferent" cells along the course of migration and in the anlagen of these plexuses. The vagus ganglia and the walls of the hindbrain, therefore, constitute a source which is sufficient to account

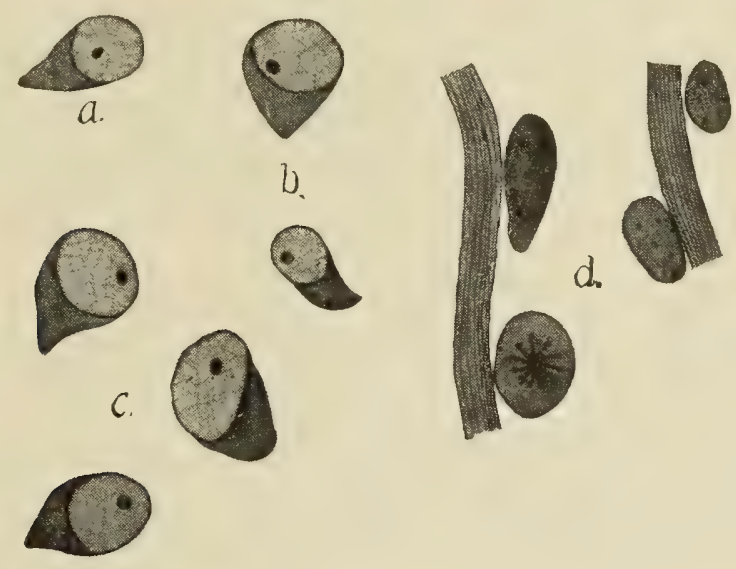

FIG. 17. Neuroblasts and indifferent cells located in the vagi and the ganglia of the trunk, $\times 1100$.

$a$., Neuroblast in the vagus rootlets. $b$., Neuroblasts in the vagus trunks. $c$, Neuroblasts in the ganglia of the trunk. $d$., Bundles of fibers with accompanying indifferent cells, from the vagus trunks.

for all the cells which take part in the early development of the vagal sympathetic plexuses. Migrant cells cannot be traced from the sympathetic trunks into the anlagen of these plexuses until the nerves connecting the latter with the sympathetic trunks are present. At this time the vagal sympathetic plexuses are well established, and the great majority of the cells taking part in their development are already present. We may conclude, therefore, that the nerves entering the vagal sympathetic plexuses 
from the sympathetic trunks represent later connections, and play only a secondary part in their development.

These conclusions differ widely from the views hitherto generally accepted concerning the development of the cardiac plexus and the sympathetic plexuses in the walls of the visceral organs, but the facts on which they are based are perfectly clear. Furthermore, they obviate certain difficulties which arise in any attempt to derive these plexuses from the sympathetic trunks. The anlagen of the sympathetic plexuses in the walls of the visceral organs are present before any traces of the prevertebral plexuses or of cells migrating peripherally from the sympathetic trunks are found. It is obvious, therefore, that the vagal sympathetic plexuses cannot be derived from the sympathetic trunks. These findings also give the vagi an importance in the development of the sympathetic nervous system which has hitherto been unrecognized, but which is in complete harmony with other known facts.

\section{DISCUSSION OF RESULTS, AND CONCLUSIONS}

(a) Migration of medullary cells.-Neurological literature contains frequent allusions to the migration of medullary cells ever since the time of Balfour ('75). That pioneer among the investigators of the histogenesis of nerve-forming elements observed cells which he believed to be nervous elements, migrating from the embryonic neural tube in elasmobranchs. These observations were substantiated by Beard ('88) and Dohrn ('88, '91). Herrick ('93) observed medullary elements migrating from the motor niduli into the ventral roots of the spinal nerves in amphibians, reptiles, and mammals. Ganglion cells have also been found occasionally in the motor nerve-roots in adult animals. Such cells were observed by Freud (78) in the ventral roots of the spinal nerves in Petromyzon, and by Schäfer ('81) and Kölliker ('94) in the ventral roots of the spinal nerves in the cat. Thompson ('87) described cells which he interpreted as degenerating ganglion cells, in the third and fourth cranial nerves in man.

More recent investigators have frequently observed migrant 
medullary cells and have variously interpreted them. Harrison ('01) has shown that in the salmon the spinal ganglia arise from cells which migrate out from the dorsal region of the neural tube. He also observed medullary cells migrating into the ventral roots of the spinal nerves, and suggested the possibility that these cells may migrate peripherally into the ganglia of the sympathetic trunks and there give. rise to sympathetic excitatory neurones. Bardeen ('03) observed that in mammalian embryos a certain number of cells migrate from the neural tube and the spinal ganglia along the fibers of the spinal nerves. He suggested that these cells take part in the development of the neurilemma. He believes, however, with Vignal ('83) and Gurwitsch ('00), that in mammals the neurilemma is derived largely from the mesoderm. Neal ('03) described medullary cells in the ventral roots of the spinal nerves in Squalus acanthias, and expressed the opinion that they take part in the development of the neurilemma. Carpenter ('06) has shown that in embryos of the chick medullary cells which he recognizes as the "indifferent" cells of Schaper, migrate from the walls of the mid-brain along the fibers of the abducent and the oculomotor nerves. According to Carpenter most of these cells become distributed along the nerve-trunks and may be recognized as the cells which give rise to the neurilemma. In the oculomotor nerve, however, some of these "indifferent" cells migrate farther peripherally and give rise to neurones in the ciliary ganglion. Carpenter and Main ('07) are of the opinion that some of the medullary cells which they observed migrating into the ventral roots of the spinal nerves in embryos of the pig become cells of the neurilemma and there subserve a supporting function similar to that of the neuroglia cells in the central nervous system. Cajal ('08) described elements which he recognizes as nerve cells in the bipolar phase, in the ventral roots of the spinal nerves and certain of the cranial nerves in the chick.

Although the advocates of the theory of local differentiation and the multicellular nature of nerve-fibers reject the theory of the migration of nervous elements, the results of recent researches are so convincing that we must accept the migration of medullary 
cells as a fact. The present series of observations shows, moreover that the migration of medullary elements plays a far more important rôle in the development of the peripheral nervous system than has hitherto been admitted. Direct observations have shown that medullary cells migrate into the ventral roots of the spinal nerves and into the roots of several of the cranial nerves. The present observations have further shown that such cells migrate also into the dorsal roots of the spinal nerves and into the roots of the vagus and the spinal accessory nerves. I have also observed medullary cells migrating into the semilunar ganglia. Furthermore, it has been shown that some of the cells which migrate peripherally from the neural tube and the cerebrospinal ganglia give rise to the sympathetic nervous system.

(b) The neurilemma.-An extended discussion of the development of the neurilemma is beyond the scope of this paper. Inasmuch, however, as the histogenesis of the neurilemma is so intimately related to the histogenesis of the sympathetic neurones, its origin may be considered briefly at this point. As the "indiffent" cells migrate peripherally from the neural tube and the spinal ganglia, they migrate not only into the anlagen of the sympathetic trunks but also along the growing fibers beyond the origin of the communicating rami. These cells as well as the cells which, as has been shown, remain distributed along the nerve-trunks after migration has ceased, obviously take part in the development of the neurilemma. They cannot be accounted for in any other way.

Not a few of the more recent investigators, including the advocates of the theory of local differentiation and the multicellular nature of nerve-fibers, are of the opinion that the neurilemma is of ectodermal origin. We agree with the advocates of local differentiation on this point, but we must disagree with them as to the manner in which the cells giving rise to the neurilemma arise and are distributed along the nerve-fibers. It is significant that Kölliker ('05), though formerly of the opinion that the neurilemma is of mesodermal origin, came to the conclusion, in his last research, that some of the cells which wander out from the spinal ganglia give rise to the neurilemma of the sensory fibers, and that the neurilemma is everywhere of ectodermal origin. Carpenter ('06) has 
shown that migrant medullary cells actually develop into cells of the neurilemma in the abducent and the oculomotor nerves in the chick.

Proof of the medullary and the ganglionic origin of the cells giving rise to the neurilemma was difficult only until it could be demonstrated that cells actually migrate peripherally from the neural tube and the cerebro-spinal ganglia along both the spinal and the cranial nerves. The present series of observations presents conclusive evidence on this point. We may here repeat what has already been stated with regard to the cells taking part in the development of the sympathetic system. We are not to suppose that all the cells taking part in the development of the neurilemma actually migrate as such from the neural tube and the cerebro-spinal ganglia. Doubtless, many arise by the mitotic division of "indifferent" cells along the course of migration. According to this interpretation, the cells of the neurilemma are homologous with the neuroglia cells in the central nervous system.

(c) Sympathetic excitatory and sympathetic sensory neurones.The problem of the histogenetic relationships of the sympathetic excitatory and the sympathetic sensory neurones presents peculiar difficulties. The presence of sympathetic sensory neurones in the sympathetic trunks and prevertebral plexuses has not been demonstrated. Froriep, like Langley, Kölliker, and P. Schultz, denies the existence of sympathetic sensory neurones entirely. There can be little doubt, however, that sympathetic sensory neurones are present in the sympathetic plexuses in the walls of the digestive tube. According to Bayliss and Starling ('99), the peristaltic contractions of the small intestine are true coördinated reflexes carried out by the local nervous mechanism (myenteric plexus). The later experimental work of Cannon ('06) and of Auer ('10) lends support to this view by showing that the peristaltic contractions of the stomach and the intestine may be carried on more or less regularly for a considerable length of time after both the vagi and the splanchnic nerves have been severed. These phenomena seem to indicate the existence of true sensory neurones in the sympathetic plexuses in the walls of the digestive tube. 
Froriep's conclusion that the sympathetic neurones have their origin in the rentral half of the neural tube and migrate out along the fibers of the rentral roots of the spinal nerves is probably correct with regard to the neurones in the sympathetic trunks and the prevertebral plexuses. I have shown, howerer, that the vagal sympathetic plexuses arise from cells which migrate peripherally along the fibers of the ragi. If, as experimental evidence indicates, so ne of these plexuses contain sensoryneurones, it is probable that these arise from cells which migrate from the vagus ganglia. While it is impossible by direct observation to trace either sympathetic excitatory or sympathetic sensory elements back to their specific source in the cerebro-spinal nerrous system, the facts at our command warrant the conclusion that the sympathetic excitatory neurones arise from cells which migrate from the neural tube along the fibers of the motor nerve roots, while the sympathetic sensory neurones, wherever such neurones exist, arise from cells which migrate from the cerebro-spinal ganglia.

The nervous elements in the neural crest obriously hare the same origin as those which remain within the neural tube; they are the descendents of the "germinal" cells of His. Retzius has shown that in amphioxus sensory neurones are found lying near the internal limiting membrane lining the slit-like central canal, some of which send their dendrites out to the skin. In the fishes also a relatively large number of cells remaining within the neural tube give rise to sensory fibers which run to the skin. In embryos of the salmon, according to Harrison, cells become separated from the neural tube and, migrating ventrally, give rise to the spinal ganglia. In embryos of the pig, as already indicated, medullary cells migrate from the dorsal region of the neural tube into the dorsal nerve-roots. All these facts suggest that the cerebro-spinal ganglia have arisen from cells which originally lay within the neural tube, and indicate the common origin of all sensory and motor neurones.

The orientation of the cells in the neural tube, during the period of migration, is such that the cells which wander into the dorsal nerve-roots seem to have their origin in the dorsal part of the neural tube, while those which migrate into the ventral nerve- 
roots wander out from the ventral zone and from the region in which later the lateral horn of the gray matter arises. This also is in full accord with the conditions in the adult nervous system. The neurones in the cerebro-spinal ganglia, as far as is known, are sensory in character, while the cells whose axones constitute the fibers of the motor nerve-roots are located in the ventral part of the neural tube. Furthermore, the investigations of Kohnstamm ('00) render the existence of efferent fibers in the dorsal nerve-roots of the higher vertebrates extremely doubtful. Inasmuch as nervous elements which have the capacity to develop into neurones migrate peripherally along both the sensory and the motor nerve-roots, we are driven to the conclusion that the sympathetic excitatory elements migrate from the neural tube along the fibers of the motor nerve roots, while the sympathetic sensory neurones, wherever such neurones exist, arise from cells which wander out from the cerebro-spinal ganglia. This interpretation makes the sympathetic neurones entirely homologous with the efferent and the afferent components of the other functional divisions of the peripheral nervous system.

(d) A wider application of Schaper's conception.-As has been shown in the preceding pages, the cells which migrate peripherally from the neural tube and the cerebro-spinal ganglia have a common origin; they are the descendants of the "germinal" cells of His; viz., the "indifferent" cells and the "neuroblasts" of Schaper. Therefore, Schaper's conception of the developmental relationships of the neurones and the supporting elements in the central nervous system may be extended to the sympathetic neurones and the cells of the neurilemma.

(e) The relation of the sympathetic to the central nervous system.In the light of the present investigation, the sympathetic system bears a direct genetic relationship to the central nervous system. The cells giving rise to the sympathetic trunks, and the prevertebral plexuses migrate peripherally along the spinal nerves, while those giving rise to the vagal sympathetic plexuses migrate peripherally along the vagi. The cells giving rise to the sympathetic neurones, however, all have the same genetic relationships; they are the descendants of the "germinal" cells of His. 
Therefore, the sympathetic neurones are homologous with the neurones in the central nervous system.

The sympathetic system is not a nervous mechanism separate from the central nervous system, but the nervous system is a unit of which the sympathetic system is a part homologous with the other functional divisions. It may be looked upon as an accession to the nervous system which has arisen comparatively late in the evolution of vertebrates, in response to an increasing demand for a nervous mechanism of a lower order, which might assume the direct control of the purely vegetative functions.

(f) Functional relations. - The reader will, undoubtedly ask what bearing the facts set forth in the preceding pages may have on physiological and psychological problems involving the sympathetic system. This question we cannot hope to answer at present. We may, however, offer a few suggestions which have presented themselves during the progress of this investigation.

Our knowledge concerning the functional relations and the physiological activities of the sympathetic system is very limited. Nor could we hope for much progress in this direction as long as the developmental relationships of the sympathetic to the central nervous system were not definitely known. The fact that the sympathetic system is homologous with the other functional divisions of the nervous system lends a new aspect to the entire problem. The fact, however, that the vagal sympathetic plexuses have their origin in the hind-brain and the vagus ganglia will probably be of even greater physiological and psychological importance. This fact indicates a close relationship between the lower centers of the brain and the innervation of the heart and the visceral organs. The suggestion is here ventured that in this relationship will probably be found the basis of certain physiological and psychological problems involving the digestive functions and the action of the heart, which have hitherto been obscure.

Here is a field for investigation which challenges the attention of both the student of physiology and the student of psychology. It is beset with the greatest difficulties, but promises to be fruitful of the most far-reaching results. 


\section{SUMMARY}

1. The sympathetic trunks arise as a pair of cell-columns lying along the sides of the dorsal surface of the aorta. In the early stages, medullary cells migrate from the neural tube into the dorsal and the ventral nerve-roots. The cells which migrate into the ventral nerve-roots, with similar cells which wander down from the spinal ganglia, migrate peripherally along the spinal nerves. Some of these cells deviate from the course of the spinal nerves and, migrating along the paths of the communicating rami, give rise to the sympathetic trunks. These findings differ materially from those of the earlier investigators. They agree essentially with the findings of Froriep.

2. The prevertebral plexuses arise as cell-aggregates lying along the ventro-lateral aspects of the aorta in the posterior region of the body. They are derived directly from the sympathetic trunks.

3. The cardiac plexus and the sympathetic plexuses in the walls of the visceral organs are not derived from the sympathetic trunks, as has hitherto been supposed, but have their origin in nervous elements which migrate from the hind-brain and the vagus ganglia along the fibers of the vagi. In view of the relation of these plexuses to the vagi, the author has chosen to designate them as "vagal sympathetic" plexuses. These findings give the vagi an importance in the development of the sympathetic system which has hitherto been unrecognized.

4. The cells migrating peripherally from the cerebro-spinal system along the spinal nerves and the vagi are the descendants of the "germinal" cells of His; viz., the "indifferent" cells and the "neuroblasts" of Schaper. Therefore they are homologous with the cells giving rise to the neurones and the supporting elements in the central nervous system.

5. The cells migrating peripherally along the spinal nerves and the vagi do not all take part in the development of the sympathetic system. Some become distributed along the nervefibers and give rise to the neurilemma. Therefore, the cells of 
the neurilemma are homologous with the neuroglia cells in the central nervous system.

6. The cells taking part in the development of the sympathetic nervous system and the neurilemma do not all actually migrate as such from their sources in the cerebro-spinal system. Doubtless, many arise by the mitotic division of "indifferent" cells along the course of migration.

7. The existence of sympathetic sensory neurones in the sympathetic trunks and the prevertebral plexuses has not been demonstrated. Experimental evidence, however, indicates the presence of sympathetic sensory neurones in the sympathetic plexuses in the walls of the digestive tube. While it is impossible, by direct observation, to trace either sympathetic excitatory or sympathetic sensory elements back to their specific source in the cerebro-spinal nervous system, indirect embryological and anatomical evidence warrants the conclusion that the sympathetic excitatory neurones arise from cells which migrate from the neural tube along the fibers of the motor nerve-roots, while the sympathetic sensory neurones, wherever such neurones exist, arise from cells which migrate from the cerebro-spinal ganglia. This interpretation makes the sympathetic neurones homologous with the afferent and the efferent components of the other functional divisions of the peripheral nervous system.

8. Inasmuch as the cells migrating peripherally from the cerebro-spinal nervous system are the "indifferent" cells and the "neuroblasts" of Schaper, Schaper's conception of the developmental relations of the neurones and the supporting elements in the central nervous system, may be extended to the sympathetic neurones and the cells of the neurilemma. .

9. The nervous system is a unit of which the sympathetic system is a part homologous with the other functional divisions. The sympathetic system may be looked upon as an accession to the nervous system, which has arisen comparatively late in the evolution of vertebrates in response to the conditions of the vegetative life. 
10. The fact that the sympathetic system is homologous with the other functional divisions of the nervous system lends a new aspect to the problems involving its functional relations. The fact that the vagal sympathetic plexuses have their origin in the hind-brain and the vagus ganglia will, doubtless, have an important bearing on certain physiological and psychological problems involving the heart action and the digestive functions. 
Ater, J. The effect of severing the vagi or the splanchnics or both upon gastric 1910 motility in rabbits. Amer. Jour. of Physiol., vol. 25, pp. 334-344.

BALfour, F. M. The development of elasmobranch fishes. Development of 1877 the spinal nerves and the sympathetic nervous system. Jour. of Anat. and Physiol., vol. 11.

1880 Comparative embryology, vol. 2, pp. 384-386.

BARDEEN, C. R. The growth and histogenesis of the cerebro-spinal nerves in 1903 mammals. Amer. Jour. of Anat., vol. 2, pp. 231-257.

Barliss AND Starling. The movements and innervation of the small intestine. 1899 Jour. of Physiol., vol. 24, pp. 99-143.

BEARD, J. Morphological studies. 2. The development of the peripheral nervous 1888 system of vertebrates. Part 1.-Elasmobranchii and aves. Quart. Jour. of Micr. Sci., n. s., vol. 29, pp. 153-227.

CaJAL, S. R. Nouvelles observations sur l'évolution des neuroblastes, avec 1908 quelques remarques sur l'hypothèse neurogénétique de HensenHeld. Anatomischer Anzeiger, Bd. 22, pp. 1-25 and 65-78.

CAnron, W. B. The motor activities of the stomach and small intestine after 1906 splanchnic and vagus section. Amer. Jour. of Phsiol., vol. 17, pp. 429-442.

Carpenter, F. W., The development of the oculomotor nerve, the ciliary gan1906 glion, and the abducent nerve in the chick. Bull. Mus. Comp. Zoōl., Harvard College, vol. 48, pp. 141-228.

Carpenter, F. W., And Main, R. C. The migration of medullary cells into th. 1907 ventral nerve-roots of pig embryos. Anatomischer Anzeiger, Bd 31, pp. 303-306.

DонRn, A. Studien zur Urgeschichte des Wirbelthierkörpers. Nr. 17. Nerven. 1891 faser und Ganglienzelle. Histogenetische Untersuchungen. Mitteil. d. Zoölog. Station zu Neapel, Bd. 10.

1901 Studien zur Urgeschichte des Wirbelthierkörpers. Die Schwannschen Kerne, ihre Herkunft und Bedeutung. Erwiderung an A. v. Kölliker. Mitteil. d. Zoölog. Station zu Neapel, Bd. 15.

Froriep, A. Die Entwickelung und Bau des autonomen Nervensystems. Medi1907 zinisch-naturwiss. Archiv, Bd. 1, pp. 301-321.

Gurwitsch, A. Die Histogenese der Schwannschen Scheide. Archiv f. Anat. 1900 u. Physiol., Jahrg. 1900, anat. Abt., pp. 85-94.

Harrison, R. G. Ueber die Histogenese des peripheren Nervensystems bei Salmo salar. Archiv f. mikr. Anat., Bd. 57, pp. 354-444.

1904 Neue Versuche und Beobachtungen über die Entwickelung der peripheren Nerven der Wirbeltiere. Sitzungsber. d. Niederrhein. Ges. f. Nat. u. Heilkunde zu Bonn, 1904, B., S., 55.

1906 Further experiments on the development of peripheral nerves. Amer. Jour. of Anat., vol. 5, pp. 121-131. 
Hıs, W. Ueber die Anfänge des peripheren Nervensystems. Archiv f. Anat. $u$. 1879 Physiol., anat. Abt., pp. 455-482.

1888 Zur Geschichte des Gehirns sowie der centralen und peripherischen Nervenbauen beim menschlichen Embryo. Abhld. d. Sächs. Gesell. Wiss., Math-phys. Classe, Leipzig, Bd. 14, pp. 339-392.

1889 Die Neuroblasten und deren Entstehung im embryonalen Mark. Archiv f. Anat. u. Physiol., Jahrg. anat. Abt., pp. 249-300.

His, JR., W. Die Entwickelung des Herznervensystems bei Wirbelthieren. 1891 Abhdl. Math-physischen Classe d. Königl. Sächsischen Gesell. d. Wiss., Bd. 8, Leipzig,

1897 Ueber die Entwickelung des Bauchsympathicus beim Hühnchen und Menschen. Archiv Anat. u. Entwg., Supplement.

Hoffmann, C. K. Zur Entwickelung des Sympathicus. I. Die Entwickelungs1900 geschichte des Sympathicus bei den Selachiern (Acanthias vulgaris), Verhdl.d.Königl.Akad.v.Wetensch.te Amsterdam. (Tweede Sectie), Deel vii.

1902 Zur Entwickelung des Sympathicus. II. Die Entwickelungsgeschichte des Sympathicus bei den Urodelen. Verhdl. d. Königl. Akad. v. Wetensch. te Amsterdam, Deel viii.

Huber, G. Carl. Lectures on the sympathetic nervous system. Jour. Comp. $1897 \quad$ Neurol. and Psychol., vol. 7, pp. 73-145.

Johnston, J. B. The nervous system of vertebrates. Philadelphia. 1906

Jones, W. C. Notes on the development of the sympathetic nervous system in the 1905 common toad. Jour. Comp. Neurol. and Psychol., vol. 15, pp. 113131.

Конм, A. Ueber die Entwickelung des peripheren Nervensystems. Verhdl. d. 1905 anat. Gesell. auf d. 19 Versamml. in Gemf. Ergänzungsheft zum 27. Bd.d. Anat. Anz., Jena.

1907 Ueber die Entwickelung des sympathischen Nervensystems der Säugetiere. Archiv f. mikr. Anat., Bd. 70, pp. 266-317.

Конnstamm, O. Zur Theorie des Reflexes von hinterer Wurzel auf hintere Wur1900 zel. Zentralbl. f. Physiol., Bd. 14, p. 457.

KöLliker, A. Ueber das Vorkommen von Nervenzellen in den vordern Wurzeln 1894 der Rückenmarksnerven der Katze. Verhdl. Gesell. Naturf. u. Aerzte. 66. Versamml., Theil 2, Hälfte 2, p. 363.

1905 Die Entwickelung der Elemente des Nervensystems. Zeitschrift $f$. Wiss. Zoöl., Bd. 82, pp. 1-38.

Kuntz, A. A contribution to the histogenesis of the sympathetic nervous system. 1909 Anatomical Record, vol. 3, pp. 458-465.

1909 The rôle of the vagi in the development of the sympathetic nervous system. Anatomischer Anzeiger, Bd. 35, pp. 381-390.

Lillie, F. R. The development of the chick, pp. 256-261. New York, 1908 
Marcus, H. Ueber den Sympathicus. Sitzungsbericht d. Gesell. f. Morph. u. 1909 Physiol. in München.

Neal, H. V. The development of the ventral nerves in the Selachii. Mark Anni1903 versary Volume, New York, pp. 291-313.

Neumayer, L. Histogenese und Morphogenese des peripheren Nervensystems, 1906 der Spinalganglien und des Nervus Sympathicus. Handbuch der vergl. u. experiment. Entwickelungslehre der Wirbeltiere, Bd. 2, 3. Theil, pp. 513-626.

ONodi, A. D. Ueber die Entwickelung des sympathischen Nervensystems. 1886 Zweiter Theil. Archiv f. mikr. Anat., Bd. 26, pp. 291-313.

Paterson, A. M. Development of the sympathetic nervous system in mammals. 1890 Phil. Trans. of the Royal Society, vol. 181, pp. 159-186.

REMAK. On the independent alimentary nervous system. Berlin. 1847

SCHÄFER, A. E. Notes on the occurrence of ganglion cells in the anterior roots of 1881 the cat's spinal nerves. Proc. Roy. Soc. London, vol. 31, p. 348.

Schaper, A. Die früesten Differenzierungsvorgänge im Zentralnervensystem. $1897 \quad$ Kritische Studie und Versuch einer Geschichte der Entwickelung nervöser Substanz. Archiv f. Entw.-Mech., Bd. 5, pp. 81-132.

SchencK, S., ANd Birdsali, W. R. Ueber die Lehre von der Entwickelung der 1878 Ganglien des Sympathicus. Mitteil. aus d. embryol. Instit. iii, Wien.

VAN WiJhe, J. W. Ueber die Mesodermsegmente des Rumpfes und die Entwicke1889 lung des Exkretionssystems bei Selachiern. Archiv f. mikr. Anat., Bd. 33 .

Vignal, W. Mémoire sur le développement des tubes nerveux chez les embryons 1883 de mammifères. Archives de Physiol. norm. et pathol., 3. série, T. I. Paris. 

LIBRARY OF CONGRESS

00272755504 
METAL EDGE, INC. 2008

PH7.5 TO 9.5 PA.T. 
LIBRARY OF CONGRESS

00272755504 